\title{
Coherence of the Rules of Sharia Against Pancasila
}

\section{Zaidah Nur Rosidah}

Fakultas Syariah, Institut Agama Islam Negeri Surakarta, Indonesia

Email Coresponden: zaidahnurr@yahoo.com

\begin{abstract}
This paper aims to find the coherence of sharia principles towards Pancasila. Pancasila as the philosophical basis of the state has an important role in the life of the nation and state. The principles of sharia are important principles for Muslims in muamalah. The type of research used is normative legal research to find coherence between sharia principles in Pancasila. The approach used is a conceptual approach. Secondary data were collected through literature study. Analyze the data using the syllogism method of deduction and interpretation, where the sharia principle is coherent with Pancasila. The results showed that first, the concept of ownership of property and payment of zakat and justice is coherent with the first, second and fifth precepts of Pancasila. Second, the principle of willingness is coherent with the second principle of humanity which is just and civilized, the principle of equality is coherent with the third principle of Indonesian unity, the principle of honesty and truth is coherent with the principle of the Almighty God and the second principle of fair and civilized humanity, the principle of benefit and mutual advantageous in line with the fifth precepts of social justice for all Indonesian people, the written principle in sharia principles is in line or coherent with the fourth principle of populism, which is led by wisdom in deliberation / marriage.
\end{abstract}

Keywords: Coherence; Sharia Principles; Pancasila.

\begin{abstract}
Abstrak
Tulisan ini bertujuan untuk menemukan koherensi prinsip-prinsip syariah terhadap Pancasila. Pancasila sebagai dasar filosofis negara mempunyai peran penting dalam kehidupan berbangsa dan bernegara. Prinsip-prinsip syariah merupakan prinsip penting bagi umat Islam dalam bermuamalah.Jenis penelitian yang digunakan adalah penelitian hukum normatif untuk menemukan koherensi antara prinsip syariah dalam Pancasila. Pendekatan yang digunakan adalah pendekatan konseptual. Data sekunder dikumpulkan melalui studi pustaka. Aanalisa data menggunakan metode silogisme deduksi dan interpretasi, dimana prinsip syariah dikoherensikan terhadap Pancasila. Hasil penelitian menunjukan bahwa pertama, konsep kepemilikan harta dan pembayaran zakat dan keadilan koheren dengan sila pertama, kedua dan kelima Pancasila. Kedua, asas kerelaan dan konsensualisme koheren dengan sila kedua Kemanusiaan yang adil dan beradab, asas persamaan hukum koheren dengan sila ketiga persatuan Indonesia, asas kejujuran dan kebenaran koheren dengan sila Ketuhanan Yang Maha Esa dan sila kedua kemanusiaan yang adil dan beradab, asas manfaat dan saling menguntungkan sejalan dengan sila kelima keadilan sosial bagi seluruh rakyat Indonesia, asas tertulis dalam prinsip syariah sejalan atau koheren dengan sila keempat kerakyatan yang dipimpin oleh hikmah kebijaksanaan dalam permusyawaratan/perkawilan.
\end{abstract}

Kata kunci: Koherensi; Prinsip Syari'ah; Pancasila. 


\section{Introduction}

Pancasila as the state's metaphysical foundation has a very important role in nation-state life. All facets of Indonesian life can not be removed from Pancasila's core principles. So it is fair to conclude that Pancasila is an Indonesian people's attitude of view and way of life (Fais Yonas Bo'a, 2018). In Indonesia Muslims are guaranteed their fundamental rights in carrying out their religious teachings as part of the country. Bermuamalah is one significant aspect of Muslim life in Indonesia. In Islam there are no strict constraints for running the side of life, bermuamalah, in theory. Since practically all bermuamalah practices permitted so long as there are no limitations. Muslims may make transactions with fellow Muslims or with other people besides Islam while carrying out activities bermuamalah.

It is in carrying out these bermuamalah practices that the Islamic teachings have given signs in bermuamalah that Muslims will follow. Signs of the rules in religious law that are then applied in everyday life or in contracts made are a representation of the Bermuamalah life. To find out if norms or standards are breached or not specific norms are required in religious teachings (Nurfaizal, 2013). As regards carrying out bermuamalah practices in Indonesia, there is also ijma 'ulama for Muslims relating to the laws that already exist in the faith, including the Koran and the Hadith. In Indonesia, ulama representation is governed by the Ulema Council of Indonesia. The operations of Islamic financial institutions in Indonesia make reference to the rules through MUI fatwas.

The philosophy our country has embraced, however, is Pancasila, and so the values that have been introduced and constitute teachings derived from Islamic religious norms have coherence with Pancasila. This paper aims to see the coherence of Islamic values with Pancasila as the cornerstone of state theory. Legal growth centered on Pancasila must be directed towards the development and advancement of law according to the nature and progress of technology occurring in other fields. And in order to promote national unity and dignity, the principles found in Pancasila should establish justice, order and legal certainty. And our future national law development is sensitive legal development. The sensitive national legislation is focused on the principles of Pancasila. (Teguh Prasetyo and Arie Purnomosidi, 2015). As for this study, it will define and illustrate in depth as well as comprehensively relevant to Pancasila as state theory, as well as the coherence with Pancasila of sharia concepts.

\section{Research Methods}

The type of research used in compiling this research is normative legal research that is completed with interviews. Thus what is examined initially is secondary data, then proceed with interviews. Normative legal research prioritizes library research, namely the activity of collecting data from various literatures both from libraries and other places. (Hermawan Wasito, 1997) This normative legal research focuses on the principles of law, legal systematics, law synchronization, legal history in the formation The Constitutional Court and state institutions in Indonesia (Soerjono Soekanto, 2018) This study uses 
secondary data. Secondary data collection tools in the form of books relating to the theory and concept of research objects, related articles, literature of scientific papers and so on through literature study (Maria SW. Sumardjono, 2014) Analysis of the data used in this study is the analysis of the analysis The data uses the method of syllogism of deduction and interpretation, where the sharia principle is coherent with Pancasila (Suharsimi Arikunto, 2018)

\section{Discussion}

\section{Pancasila as the Basis of State Philosophy}

Pancasila as the view of life of the Indonesian nation which includes values from divine values to justice values is a very complete and systematically arranged hierarchical arrangement. From these values should be a benchmark to weigh and decide whether something is good or bad, right or wrong (Sudjito Atmoredjo, 2019). The values contained in Pancasila basically have been rooted in the customs and habits of the Indonesian people. This means that the practice of Pancasila takes place spontaneously, instantaneously, simultaneously, simultaneously with the practice of customs, spaciousness and facilitation of people who want to carry out their customs, culture and religion. Pancasila is not a religion, so it is not appropriate for Pancasila to be compared with religion. Anyone who is religious, he has Pancasilais. (Sudjito Atmoredjo, 2019).

Pancasila is the basis and ideology of the state which is a noble agreement conceptualized by the founders of the nation which is difficult to be replaced by others. Because Pancasila is a guiding star as a legal ideal (rechtsidee) (Bernard Arief Sidharta, 2013). For the formation of positive law must complain to the basic ideas contained in Pancasila. So in the formation of the law the implementation cannot be separated from the values contained in Pancasila (Lego Karjoko, 2017). To facilitate the formation and elaboration of legal instruments, rules of authority, the understanding of Pancasila values is a necessity. The legal system to be formed should be a copy of the Pancasila ramification into a legal system that contains principles and rules. In line with that, the sharia principles that are used as the basis for transactions or contracts used by Islamic financial institutions or the basis used by judges in solving sharia economic disputes should also be based and refer to Pancasila values. (Bernard Arief Sidharta, 2013).

Pancasila as a united philosophical system is a basic ontological principle of the Pancasila precepts. The ontological basis of Pancasila is essentially a human who has the absolute nature of monopluralis. (Kaelan, 2002). The main supporting subjects of the principles of Pancasila are human beings, this can be explained as follows: that the Godly God, the humanity that is just and civilized, the united, the populist is led by the wisdom of the wisdom in deliberation / representation and the social justice in the civilized the essence is human. One of the main supporters of the state is the people. The people themselves are humans, so the atropological base of the values of the Pancasila is the people. (Lego Karjoko, 2017). As a philosophical system, according to Notonagoro, the foundation of the Pancasila precepts in terms of their contents shows a graded essence of meaning, and has the following pyramid shape. (Kaelan, 2002). 
In the precepts of the Godhead is the basis and soul for other precepts. Namely animating and underlying the precepts of fair and civilized humanity, the unity of Indonesia, the people who are led by wisdom in the deliberation of representation, and social justice for all the people of Indonesia. This is based on the nature of the main supporters of a country is the people, and the people are human beings who are creatures of God Almighty as the primary cause (Kaelan, 2002). According to Darmodihardjo in Sutjito, in the first precepts of the Almighty God contained the understanding and belief in the existence of a god who created the universe and its contents. Then in the first precepts it becomes a source of national and state life values that underlies and animates and guides the realization of fair and adapted humanity, the realization of the unity of Indonesia, forming a populist sovereign state that is led by wisdom in deliberation / representation to realize justice social for all Indonesian people (Sutjito Atmoredjo, 2018).

In the principle of humanity which is just and beradap based on and imbued with the first precept that is the Godhead of the Almighty. On the other hand, a just and civilized precepts of humanity animates and underlies the third, fourth and fifth precepts, namely the unity of Indonesia, the people who are led by wisdom in consultation / representation and social justice for all Indonesian people. The essence of this understanding is that the people who are the main elements of a country are basically individual humans who unite to form a totality in an area that aims to live together to realize social justice, namely justice in human life together as individual beings and social beings (Kaelan, 2002). The precepts of Indonesian unity are based on and imbued with the precepts of the Unity of God and humanity that is just and harmonious. On the other hand this third precepts animates and underlies the fourth and fifth precepts namely populistism led by wisdom in deliberation / representation as well as social justice for all Indonesian people. The essence of this precept is that the unity of individuals who live together is a basic part of the state element namely the people. Fellowship of life with humans in order to realize a common goal, namely justice in common life (social justice) so that the third precept underlies and animates the fourth and fifth precepts of Pancasila (Kaelan, 2002).

People's precepts are led by wisdom in the deliberative deliberations based on and imbued with the first, second and third precepts. On the other hand this fourth precept underlies and animates the precepts of social justice for all Indonesian people. The essence of this fourth precept is that the state exists in order to provide the welfare of the people, namely the realization of social justice (Kaelan, 2002). Unlike the previous precepts, the fifth precept is based on and imbued by the other four precepts. The aim of the four precepts is social justice. Ontologically, the essence of social justice is justice as it is contained in the second precepts, namely fair and civilized humanity. According to Notonegoro justice contained in the second precept is essentially human justice to himself, justice to fellow human beings and justice to his Lord. The incarnation of social justice is essentially inseparable from its nature as a human being, where humans as individual beings and social beings are in the form of justice in living together 
or social justice. Thus the logic of social justice is based on and imbued with the second principle, which is fair and civilized humanity (Kaelan, 2002).

Basically Pancasila as a fundamental state becomes the basis in every application of a rule of law. The principle of Godhead is the basis of kerokhanian, the moral basis for the Indonesian people in the implementation of state and community life. In this first precept implies that religious values have the highest position in the state so that each statutory regulation may not conflict with the first precept. Religious law originating from God is a source of values that must be followed in the formation of positive law because basically it is not only humans who believe in the Almighty, but the country also has almighty God (Kaelan, 2002).

In the principle of humanity which is just and beradap implies that it is fair, in relation to humanity which is fair to itself, to fellow human beings and to their Lord. On the basis of the understanding of humanity that is just and civilized above, in the practice of international relations, there must also be a fair understanding in relations with fellow nations and countries of the world. Civilized, namely the implementation of all the elements of human nature. It is all in the form of the implementation of a dignified life as high as possible, then a civilized human being that is carrying out his humanity that carries out his nature as a human being (monopluralis) optimally, then in the realization of Indonesia's development goals namely the realization of 'full humanity' (Kaelan, 2002).

Just human beings are civilized humans, and vice versa. Because, fair and civilized is a pair of values that are always comparable. Civilized human beings are human beings who behave in harmony with others based on the principle of equality and equity. Such an attitude can be realized if it is based on the principles as stated by Ulpianus, namely honeste vivere (live honestly), alterum non leadera (do not harm others), sum cuique tribuere (give what is part of it). By behaving in this way there will be harmonious relations between individuals, between groups and between individuals and groups (Lego Karjoko, 2017). The principle of unity is interpreted as Unity in Diversity, that is, even though the Indonesian nation and state consists of a wide variety of ethnic groups that have diverse cultures and customs, as well as diverse islands in the Indonesian territory, but the whole is a unity, namely the nation and nation Indonesian country. The diversity is not a conflicting difference, but rather diversity is united in a synthesis which in turn enriches the nature and meaning of the unity of the Indonesian nation.

The state overcomes all classes in society. The state does not favor one of the groups, the state works in the interests of all the people. This is a consequence that the state is essentially the community itself, therefore the state for all groups, all sections and all people. In other words, this third precept is also a joint law harmony, especially a joint for legal pluralism. Uniforming the law (legal unification) in a pluralistic Indonesian society will lead to injustice (Lego Karjoko, 2017). There are two ideals contained in the precepts of 'Population led by wisdom in consultation / representation', namely: (Kaelan, 2002) 
1) Democracy is the philosophical ideal of democracy, namely:

a) Political Democracy, in relation to the implementation and administration of the state in the political field, or 'equality in the political field'.

b) Socio-economic democracy, i.e. in relation to the implementation and administration of the state in the socio-economic field or 'equality in the social and economic fields to realize shared prosperity'.

2) Consultation / Representation relating to the notion of political democracy. Then this political democracy is an absolute prerequisite for achieving 'popular'.

The values contained in the four precepts establish a harmonious relationship in the association of life. This can be achieved if based on the principle of togetherness, not imposing one's own will, not relying on power, in all respects based on deliberation to reach consensus (Lego Karjoko, 2017). The precepts of social justice when returned to the basis of kerokhanian namely the nature of human nature that is 'monodualist' that is dynamic balance. Therefore, the consequences are that individual interests (individuals) (special interests) and public interests must be in a dynamic balance, which must be in accordance with the circumstances, times and developments of the times. The state maintains both the public interest and the interests of individual citizens, who are in principle the custodians of the individual (Kaelan, 2002).

In the practice of administering the State, the principle of social justice includes the maintenance of the public interests of the State as the state, the common interests of the common citizens, the common interests and special interests of individual citizens, families, ethnic groups, and each class of citizens (Kaelan, 2002) . In the nature of justice is the fulfillment of everything that is a right in the relationship of human life as a mandatory. As we know that there are three human relations of life, namely to oneself, to God as a prime cause and between human beings. In relation to human relations, this is related to social justice, which is the right and obligation of every human being towards fellow human beings, as well as from each party in living together, namely society, nation and state. Thus it can be understood that rights and compulsions are elements of social justice, because in essence the elements of rights and obligations are elements that determine the realization of social justice (Kaelan, 2002).

\section{Sharia Principles in the Agreement}

Islam as one of the religions embraced by most of the Indonesian people is guaranteed its implementation by the state. Muslims who will practice their religion both in worship and muamalah get guarantees and legal protection from the state. In carrying out its economic activities or in muamalah, there are sharia principles that have been prepared and made by the Indonesian Ulema Council. MUI as one of the institutions representing ulama in Indonesia has the authority to issue fatwas. Although the position of the MUI fatwa has not yet become a 
formal normative basis in state law, it has become a foothold and role model as well as a basis for Muslims to take actions or decisions.

MUI fatwa issued in the context of carrying out muamalah activities carried out and institutionalized through the National Sharia Council. This DSN MUI fatwa is the main reference in sharia contracts used by financial institutions in issuing their products. The principles contained in sharia contracts include general principles or principles and the principles or principles contained in each form of contract. Universal principles apply to each contract, while principles that are specific, apply to a particular contract. However, each contract that will be enforced and implemented must contain both general and special principles.

According to Metwally as quoted by Eko Suprayitno, the principles of muamalah in Islam can be outlined as follows: (Eko Suprayitno, 2005).

1) Natural resources belong to God, so their use by humans must pay attention to the responsibilities in the hereafter. So that in its use humans must pay attention to the use not only for themselves but also must pay attention to the interests of others.

2) Private property rights are recognized in a limited way, there are aspects of community interests that must be considered so that to obtain personal rights must use lawful or legal methods.

3) Islam teaches humans to work and strive to obtain halal wealth by means and rules that have been determined in the scriptures, because basically every creature has been guaranteed his sustenance by Allah.

4) The right of ownership of wealth should not only be controlled by a small number of people, because it can hamper national productivity and slow the creation of people's welfare.

5) Production sources which are important for the country and which control the livelihoods of the people are guaranteed their use for the public interest.

6) Every human action is always held accountable before God, thus encouraging Muslims to avoid the ways that contain elements of usury, maisir, gharar and efforts that go beyond limits.

7) Paying zakat for those who have reached Nisab is a form of equitable distribution of the rich to the poor.

8) Riba in any form is prohibited in Islam

Gemala Dewa in Abd. Shomad introduces the principles of engagement in Islamic law: (Abd. Shomad, 2010).

1. The Principle of Freedom of Contract (Al-Huriyah), namely the parties making an agreement may not be coercive, freedom also means the rules in Islamic law that must not be violated such as transactions containing elements of usury, maisir, gharar, fraudulent bondage system , monopoly and stockpiling.

2. The principle of consensualism (Al-Ridha 'iyyah), there is a conformity of wills between the parties.

3. The Principle of Legal Equality (Al-Musawah), this principle places everyone equally before the law. The existence of equality and equal 
position before the law so that in making transactions a balanced position can give birth to a fair agreement.

4. The principle of justice (Al-Is), this principle requires equal treatment of the parties and proportional in accordance with agreed rights and obligations. In this principle of justice the element of oppression against the weak must be avoided. Contracting parties must be open to each other to express their wishes and wishes.

5. The principle of honesty and truth (Ash-Shidiq) which emphasizes the parties who made an agreement not to commit fraud. Both must be honest about the situation that will be promised because with the existence of fraud or abuse, the situation is basically an agreement.

6. The principle of benefit that the agreement of the parties must provide benefits between the two parties. Transactions that are not useful will be in vain and wasteful and not recommended even prohibited. Such as drug trafficking which can damage the soul and reason, gambling and prostitution.

7. The Principle of Mutual Benefit (At-Ta'awun), each agreed contract must be beneficial for both parties.

8. Written Principle (Al-Kitabah), namely for the good of the parties, the contract should be made in writing, so that if there is a dispute, the injured party will be easier to prove.

According to M. Umer Chapa in Abd Shomad argued that commerce is a permissible principle, this means that not all commerce is permitted by Islam. There are general principles that must be avoided in commercializing such as usury, exploitation that can lead to injustice. He demanded the elimination of fraud, uncertainty or speculation, and monopoly or monosopoly. All business practices that cause exploitation of buyers or sellers or barriers to fair competition must be effectively banned (Abd. Shomad, 2010).

In principle, justice can be interpreted as a proportional distribution to the parties, such as the distribution of profit sharing ratios and profit margins must look at the proportionate paid-up capital and the proper distribution of profits. To get a balanced proportion, the parties must be open and mutually correct in expressing their wishes in the agreement. This is to avoid oppression to those who are in a position of need (Abd. Shomad, 2010). Likewise, the principles in a sharia contract referring to Article 21 of the Compilation of Sharia Economic Laws can be described as follows: (Beni Ahmad Saebani, 2018)

a. Ikhtiyari / voluntary, every contract should be done with the willingness of both parties, there should be no coercion from any party and pressure from others.

b. Trustful / keep promises, agreements that have been reached by the parties should be carried out properly to avoid the other party's breach of contract.

c. Effort / circumspection; so that disputes do not arise, in making the contract it should be done with careful consideration and carried out carefully and appropriately. 
d. Luzum / unchanged; to avoid the practice of speculation and chance, each will be done clearly and with careful calculations.

e. Win-win solution; each contract should be made on the basis of mutual benefit of both parties. There must be no element of manipulation so that there is one party that is harmed.

f. Taswiyah / equality; everyone has the same position in the loading of the contract, this is to avoid the rights and obligations that are not balanced.

g. Transparency; there must be openness between the parties so that the contract made can be justified.

h. Ability; the agreed contract should pay attention to the ability of the parties so that no party gets a burden beyond its ability.

i. Taisir / convenience; each contract is made in a way that makes it easy for each party to carry out in accordance with the agreement.

j. Good faith, each contract should be made in good faith and not contain elements of entrapment or other bad deeds.

$\mathrm{k}$. Because that is halal, a contract that is made must not be contrary to the law, avoided from something that is unlawful and is not prohibited by law

\section{Coherence of Sharia Principles on Pancasila}

In this paper, the coherence of sharia principles towards Pancasila is not to compare the sharia principles contained in religious teachings with Pancasila values. However, as an effort to show the linkage or coherence between the principles of sharia to the values of Pancasila as mentioned above that Pancasila is not a religion. One of the values in Pancasila is the value of God as stated in the first precept. Godliness shows that the Indonesian nation is a religious nation. The state guarantees every religion follower to practice his religion and beliefs. Such guarantees in our constitution are contained in Articles 28 and 29 of the 1945 Constitution.

Coherence or the relationship between Islamic principles and Pancasila basically has existed since humans live in society. The principles of sharia derived from religious law in this case the Islamic religion are the principles contained in the scriptures which are instructions from God for mankind. So if it is associated with Pancasila as the paradigm of legal formation, this is inseparable from the first precept, namely the Almighty God. In the first precepts of the Pancasila it clearly shows that the Indonesian people recognized the existence of god, whatever religion professed by citizens. No exception for citizens who are Muslim, in making a good agreement between Muslims and Muslims or between other religions who use sharia principles must refer to religious teachings. Likewise, law enforcers who resolve sharia economic disputes must also be guided by these sharia principles (Ali Murtadho, 2013).

The concept of ownership in the principle of sharia is coherent with the fifth principle of social justice for all Indonesian people. In essence, the concept of ownership of property is God's, so that the utilization of natural resources cannot be done by someone without regard to the interests of others. Basically the meaning contained in this fifth precepts is that the natural resources of the 
Indonesian people should be utilized for the welfare of all citizens. Likewise the concept or principle regarding the distribution of zakat that has reached nishab is essentially the distribution of wealth from the rich to the poor. This is to reduce the disparity in property ownership, as well as to provide justice that can be felt by all people or the community. The obligation to issue zakat for the rich is the coherence of the fifth precepts and the second precepts of the Pancasila, and certainly cannot be separated from the value contained in the first precepts. Because the payment of zakat for the rich is a form of religious obligation, then this is a form of basic values from the precepts of the Almighty God (Nurfarizal, 2013).

The sharia principle that holds the meaning of justice basically cannot be separated from the balance of interests between individuals and society. Justice is a natural human requirement, because in essence if there is injustice among fellow human beings, it will threaten the survival of the community together. Likewise in transactions or agreements to meet the needs of living together in the community. If there is a party that is harmed by another party and there is a strong oppression of the weak, then the human side of the person who commits unjust acts becomes despicable. This is in line with the second and fifth precepts of Pancasila. In principle, the second principle of humanity is just and civilized.

In sharia principles everyone has the right to get property or wealth. However, in obtaining these assets may not use illegal methods. And must avoid from elements of maisir, gharar, and usury. Ways like this can harm others. This is coherent with the just and civilized precepts of humanity. As a civilized human being, it is proper not to take actions that can make others lose or do acts that are destructive, deceiving and other actions that are unfair. The coherence of the principles of engagement in Islam as Gemala Dewa's opinion of Pancasila values can be described as follows.

That in making the contract must be based on the willingness of the parties, and there should be no coercion. There must be a fair attitude between the two parties and fulfill the principle of consensualism. In Islamic law, transactions that contain usury, maisir, gharar, bondage fraud, monopoly and hoarding are prohibited. Such willingness is basically so that the contract made provides a sense of justice for both parties. This is in line with the values contained in the second and fifth precepts of the Pancasila. In the second precept contained human values that are not not going to take actions that contain elements of oppression that result in harm to others. Likewise, the basis of the fifth precepts of social justice for all Indonesian people, shows that there are transactions that are not only for their own interests but also pay attention to the ethics of the public interest, so that the hoarding of goods that can make prices expensive will have an impact on the society.

This principle is also in line or coherent with the fourth basic value of Pancasila. That is basically an agreement agreement is an embodiment of a deliberation. The desired discussion in the values contained in Pancasila is based on and imbued with the supreme precepts of God, humanity and unity. The Principle of Equality of Law (Al-Musawah), this principle places everyone equally 
before the law. The existence of equality and equal position before the law so that in making transactions a balanced position can give birth to a fair agreement. This principle is also coherent with the second principle of Pancasila, that a balanced situation between the parties can reduce the incidence of injustice. And this fair factor is the main key to a transaction carried out or not. Usually those who feel treated fairly will be able to carry out and fulfill their achievements voluntarily, unless indeed the intention of one of the parties is in bad faith (Hendi Suhendi, 2002).

The principle of honesty and truth (Ash-Shidiq) which emphasizes the parties who made an agreement not to commit fraud. The value of honesty and truth in a transaction in the community becomes a necessity, because if there are parties who act dishonestly, it will clearly cause harm to other parties. This principle is coherent with the first precepts of Godhead and the second precepts of Humanity which are just and harmonious. The values contained in the first precepts show a correlation that human life is inseparable from religious teachings. Any religion certainly teaches people to act right and honest. Likewise in the second precept, that dishonest actions that are far from the value of truth can degrade human dignity. The second precept implies that the people are the main elements of the state and the people are the totality of individuals who unite with the aim of realizing justice in living together (social justice). (Rusjdi Ali Muhammad, 2006)

The Principle of Benefit in sharia principles implies that the agreement of the parties must provide benefits between the two parties. Transactions that are not useful will be in vain and wasteful and not recommended even prohibited. Such as drug trafficking which can damage the soul and reason, gambling and prostitution. The principle of mutual benefit (At-Ta'awun), each contract agreed upon must benefit both parties. These two principles are coherent with the fifth precepts of Pancasila. In the fifth precept, social justice is the goal of the other four precepts. Because in justice that is contained in a fair and civilized humanity. A just human being is a human being who is just about himself, towards others and against his god (Yusuf Qardhawi, 2001).

In the principle of benefits, essentially a transaction must provide benefits for both parties. Likewise, the principle of mutual benefit, human rights as monopluralists should not only benefit themselves but also pay attention to the interests of others or others so that the contract can provide mutual benefits. This can realize social justice as in the values contained in the fifth precepts of Pancasila. Social justice is basically the embodiment of the precepts of humanity that is just and civilized. As human beings who have natural characteristics as individual creatures and social creatures, it is imperative that every human being maintain relationships between individuals with one another in common life so that social justice.

Meanwhile the coherence of the written principle (Al-Kitabah) to the values in Pancasila is contained in the fourth precept. The written principle implies that for the good of the parties the contract should be done in writing, so that if a dispute occurs, the injured party will be easier to prove. In this case the 
agreement basically is the result of deliberation between the parties. To avoid disputes in the future, the agreement should be made in writing, so that if there is a party that reneges on the agreement, it can be proven again in the deed previously made. (Encyclopaedia of Islam, 2005) Although a dispute is not always settled through a court, the parties can choose consensus to obtain a win-win solution. This is based on the fourth principle of Pancasila.

\section{Conclusion}

Based on the description in the above discussion, then there are some conclusions that the author can state as follows: 1. In general principles regarding the concept of property ownership and payment of zakat and coherent justice with the first, second and fifth principles of Pancasila., 2. On the principles in making agreements or coherent agreements with the Pancasila, namely: a. The principle of willingness and consensualism is coherent with the second principle of a just and civilized humanity, b. The principle of coherent legal equality with the third principle of Indonesian unity, c. The principle of honesty and truth is coherent with the precepts of the Almighty God and the second precepts of fair and civilized humanity, $d$. The principle of benefit and mutual benefit is in line with the fifth principle of social justice for all Indonesian people, and e. The principle written in sharia principles is in line or coherent with the four precepts of populist rule, led by wisdom in consultation / marriage.

\section{References}

Ahmad Saebani, Beni , 2018, Hukum Ekonomi dan Akad Syariah di Indonesia, Bandung: Pustaka Setia.

Arief Sidharta, Bernard, 2013, Ilmu Hukum Indonesia Upaya Pengembangan Ilmu Hukum Sistematik Yang Responsif Terhadap Perubahan Masyarakat, Yogyakarta: Genta Publishing.

Atmoredjo, Sudjito, 2019, Hukum dan Kebansaan, Kemasyarakatan, Keadilan dan Keadaban, Yogyakarta: Dialektika.

Ensiklopedi Islam, 2005, jilid 5, (Jakarta: Ichtiar Baru van Hoeve).

Jaelani, Abdul Kadir, Implementasi Daluarsa Gugatan Dalam Putusan Peradilan Tata Usaha Negara di Indonesia, Pena Justisia: Media Komunikasi dan Kajian Hukum, Volume 18, No.2, 2019

Kaelan, 2002, Filsafat Pancasila Pandangan Hidup Bangsa Indonesia, Yogyakarta: Paradigma.

Karjoko, Lego, 2017, Disertasi dengan judul "Pembadanan Asas Fungsi Sosial Hak Guna Usaha dalam Pengaturan Pekebunan yang Mensejahterakan Rakyat”, Surakarta: UNS.

Murtadho, Ali, Model Aplikasi Fikih Muamalah Pada Formulasi Hybrid Contract, Al-Ahkam, Volume 23, Nomor 2, Oktober 2013

Nurfaizal, Prinsip-Prinsip Muamalah dan Inplementasinya dalam Hukum Perbankan Indonesia, Hukum Islam, Vol. XIII No. 1 Nopember 2013 2018, Hukum dalam Pelangi Kehidupan, Yogyakarta: Dialektika. 
Prasetyo, Teguh dan Arie Purnomosidi, 2015, Membangun Hukum Berdasarkan Pancasila, Bandung: Nusa Media.

Saputra, Rian, Pergeseran Prinsip Hakim Pasif ke Aktif Pada Praktek Peradilan Perdata Perspektif Hukum Progresif, Wacana Hukum: Vol. 25, No.1, Juni 2019.

Shomad, Abdul, 2010, Hukum Islam, Penormaan Prinsip Syariah dalam Hukum Indonesia, Jakarta: Kencana Prenada Media group

Suprayitno, Eko, 2005, Ekonomi Islam Pendekatan Ekonomi Makro Islam dan Ekonomi Konvensional, Yogyakarta, Graha Ilmu.

Abdul Kadir Jaelani, I Gusti Ayu Ketut Rachmi Handayani, Lego Karjoko, "The Political Law of the Constitutional Court In Canceling the Concept of the Four Pillars as an Pancasila as the State Foundation", Journal of Talent Development and Excellence, Volume 12, Issue 2, (2020)

Abdul Kadir Jaelani, I Gusti Ayu Ketut Rachmi Handayani, Lego Karjoko, "Executability of the Constitutional Court Decision Regarding Grace Period In The Formulation Of Legislation", International Journal of Advanced Science and Technology, Volume 28, Issue 15, (2019)

Bagja, H.N., Saudi, N.S.M., "Review the aspects of legal protection for consumers in e-commerce transactions in Indonesia", International Journal of Psychosocial Rehabilitation, Volume 24, Number 7 (2020)

Ayu Dian Pratiwi, Pius Triwahyudi, "Jaminan Perlindungan yang Berkeadilan bagi Tenaga Kerja Difabel Akibat Kecelakaan Kerja”, Jurnal Bestuur, Vol 7, No 2 (2019).

Liana Endah Susanti, "Economic Law Creation Beautiful Global Indonesia” Jurnal Bestuur, Vol 7, No 1 (2019).

I Gusti Ayu Ketut Rachmi Handayani, Lego Karjoko, Abdul Kadir Jaelani, "Model Pelaksanaan Putusan Mahkamah Konstitusi yang Eksekutabilitas Dalam Pengujian Peraturan Perundang-Undangan di Indonesia”, Jurnal Bestuur, Vol 7, No 1 (2019). 